\title{
Land use and urban sustainability assessment: a 3D-GIS application to a case study in Gozo
}

\author{
Rosa Morosini and Floriana Zucaro* (1)
}

\begin{abstract}
Balancing urban growth and natural resource availability has been recognized as the main challenge of the 21st century from the strategic documents adopted by the recent World Summits. Agenda 21 advocates sustainable land use, as soil is a crucial natural resource to reduce urban vulnerability due e.g. to climate change, energy saving, and natural disasters. In this perspective, this paper aims at supporting local decision makers in identifying the portions and the buildings of an urban area most susceptible to transformation, in order to promote a sustainable land use according to physical and functional characteristics. The proposed methodology combines the 3D modeling of urban settlements and the adoption of the performance-based approach by the urban transformation government, in order to guarantee the satisfaction of the supply-demand ratio through a compatible balance between urban growth dynamics and the overall urban efficiency. The test area was Gozo island, where a significant urban transformation will occur as a consequence of the new Malta-Gozo tunnel construction.
\end{abstract}

Keywords: Sustainable land management, Spatial planning, 3D-GIS models, Visibility analysis, Urban sustainability

\section{Introduction}

Since the first international Earth Summit (held in Rio de Janeiro in 1992), both government agencies and the scientific community have worked to facilitate the transition from the theoretical affirmation of sustainable development towards strategies and above all actions aimed at protecting, restoring and increasing natural resources in urban areas.

The assumption of sustainability as the main guiding principle in the choices of government of urban transformations requires the preparation of new tools, interventions and solutions to deal with the new challenges each city is required to tackle (Maciocco and Serreli 2009; Roggema 2016; Frantzeskaki et al. 2017; Gargiulo et al. 2018). These include traffic congestion and pollution, GHG emissions, intense urban sprawl, energy efficiency (Vojnovic 2014; Gargiulo and Lombardi 2016; Gargiulo and Russo 2017; Papa et al. 2017). All these issues are

\footnotetext{
*Correspondence: floriana.zucaro@unina.it

Department of Civil, Architectural and Environmental Engineering, University of Naples Federico II, Naples, Italy
}

linked to the urbanization process that is expected to increase in the coming decades (UNDP 2010) and will inevitably lead to soil degradation, unless current land use and management practices change (Assadourian and Prugh 2013; Cook and Swyngedouw 2014; Gibbs and Salmon 2015).

It is estimated that the human footprint has affected 83\% of Earth's land surface (Plumptre et al. 2019) and has degraded about $60 \%$ of the ecosystems services in the past 50 years alone (MEA 2005, 2018).

Since the Land Use and Land Cover (LULC) change project was launched by the International Geosphere and Biosphere Program (IGBP) and the International Human Dimensions Program (IHDP) on Global Change, land use research programs on a global scale have become central to international climate and environmental change research (Lambin et al. 1999; Couch et al. 2008; Han et al. 2015; Martellozzo et al. 2018).

According to Han et al. (2015) and Zhang et al. (2011), sustainable land management requires efficient development and distribution of human activities at all scales to 
preserve the natural flows among soil, water and atmosphere, in order to guarantee mainly biodiversity and food productivity.

Given that urban quality and environmental protection play a fundamental role in the development of urban policies, it would then be appropriate to adopt a new approach to urban transformations aimed at optimizing land management, in order to reduce the waste of resources, respect and increase natural vocations of places and restore their value (Zucaro and Morosini 2018): "transformative actions towards sustainability require, as a key condition, the preservation of all available resources that constitute the natural and man-made capital and contribute to the overall well-being of each generation" (Papa 2009).

The issue of finding the right balance between transformation needs and sustainable use of natural resources has triggered the scientific debate over the planning for sustainable development in coastal areas and small islands that are strongly dependent upon tourism. Developmental activities in these areas, in fact, may have negative impacts on coastal ecosystems, such as the loss of biodiversity, pollution and waste generation and urban congestion which make urban settlements located in these particular areas more vulnerable and lead to a decrease in the quality of life of inhabitants (Van der Borg 2004; La Rocca 2014; Koens et al. 2018).

In view of the opportunities offered by technological innovations in the study of urban phenomena and city governance techniques, the adoption of ITs is explained, on the one hand, by the need to develop the numerical cartography which created new development tools for spatial analysis (Fistola 2009), such as a Geographic Information System (GIS), on the other, by the significant contribution of Cybernetics and Neuroscience to the academic field of "urban modeling" (Fistola and Rastelli 2018).

In this perspective, the opportunities offered by GIS provide innovative analysis procedures and techniques for the transformation and management of urban and territorial systems (Batty and Densham 1996; Fistola 2009).

The most advanced use of these systems concerns 3D modeling which is well received by local decision makers to visualize alternative land-use plans and their impact on urban environments (Steinicke et al. 2006; Shiode and Yin 2008; Yin and Shiode 2014; Chundeli 2017).

Recent studies carried out by Yin and Hastings (2007), Biljecki et al. (2015), Julin et al. (2018) and Templin et al. (2019) developed 3D city modeling projects for managing urban transformations. This advancement of GIS and the availability of new data sources (open data, e.g. see O'Reilly 2009) have provided a growing impulse to spatial planning, also in the wake of the smart city paradigm (Prandi et al. 2014; Billen et al. 2015; Bouloukakis et al. 2019).

Among the 3D spatial analysis powerful tools, the visibility analysis allows to foresee the spatial consequences of the urban transformation interventions as it enable extracting visible and invisible zones at a given viewpoint. This analysis calculates the percentage of visible volume by identifying also which built and not built elements (e.g. buildings, hills) characterize the cityscape due to their height. Therefore, the visibility analysis can support the decision makers in understanding "how much can we see", and "how much space is enclosed" that, according to Batty (2001), represent some of the key aspects for a good urban transformation as they have influences on the human perception of the built environment, on attractiveness of landscape, on the economic evaluations of the real estate and so, generally, on the quality of life (Danese et al. 2009; Czyńska and Rubinowicz 2019).

In consideration of the aforesaid, this contribution pursues the line of thought of many engineers or architects, like Renzo Piano, who firmly believe in the need to transform cities without additional soil consumption, which means "re/build in the built environment", and proposes a 3D GIS-based methodology aimed at identifying the portions of the urban area most susceptible to transformation within already-urbanized areas, on the basis of the physical, built-up (height, land use, etc.) and context (shading areas, panoramic views, etc.) characteristics of the urban system. In particular, the proposed methodology intends to support local decision makers in detecting, among the existing buildings, those where new urban services might be introduced by intensifying infill practices, thus promoting a sustainable land management.

This paper is part of a broader research project aimed at defining a GIS Decision Support System (DSS) to identify the range of possible transformations and compatible uses of the soil resource on the urban scale. It is divided in the following sections: "Gozo island: between urban transformation and sustainability" section describes the test area of Gozo; "Methods and materials" section illustrates the 3D-GIS based methodology; "Results" section describes the results of the visibility analysis of many buildings on the historic center, thereby demonstrating that if, on the one hand, vertical development protects land use, on the other, many spectacular panoramic views of a given area (which is essentially tourism-oriented) are inevitably lost; "Conclusions" section sums up the key points of our analysis and offers suggestions for further studies. 


\section{Gozo island: between urban transformation and sustainability}

The urban settlement, the morphology, the set of natural and landscape resources and the demographic structure well differentiate the island of Gozo from neighboring mainland Malta (which is $5 \mathrm{~km}$ away) in the south of the Mediterranean Sea. Gozo covers a land area of around $67 \mathrm{~km}^{2}$, a third the size of Malta, and its economy strongly depends on the presence of tourist activities: about $30 \%$ of the GDP of the island is generated by the tourism sector (Malta Tourism Authority 2015).

Another key difference between the two islands is the demographic trend of the last 10 years: in fact, while Malta has registered an increase in the number of youth, Gozo is characterized by a more elderly population. The Gozitan population is aging, and this phenomenon was already highlighted in 2006, when the demographic forecast showed that in $201022 \%$ of the population would have been aged over 60 (Local plan 2006).

According to the most recent data on tourism growth, Gozo is expected to witness massive tourist inflows in relation to the resident population; in fact, it is estimated that the island will host an average of 300 tourists per 100 locals (Malta Ministry for Tourism 2015).

Deeper analysis of the above data reveals that a significant rate of users of accommodation facilities are people over 65 , whose presence increased by $40 \%$ in the period 2010-2017 (NSO 2018) and this percentage is expected to rise in the coming years (Malta Tourism Authority 2018). The presence of this segment of the population is destined to strongly characterize the island of Gozo, like most EU countries, due to increasing longevity. Life expectancy at birth is 79.7 years, which is above the average rate of the global population (UN 2013). It is expected that $21 \%$ of Gozo's population will be above the age of 60 by 2025 and this percentage will reach $33.7 \%$ by 2050 (Troisi 2009; Government of Malta 2011). Furthermore, by referring to the different old population segments, while the "young old" (aged 60-74) will increase by $8 \%$, the "old old" (aged 75+) will increase by $20 \%$ in the next years (Government of Malta 2011; UN 2013).

In Gozo, the demographic trend and the senior tourism described above poses many challenges for local decision makers called to promote urban planning policies and strategies aimed at enhancing the island's tourist vocation and improving the quality of life of inhabitants and city users. These issues, together with the main ones of sustainability and protection of natural resources and landscape, are given constant attention by local authorities within the Local Plan. With regard to the latter, approved in 2006, it represents the only tool of territorial planning for the islands of Gozo and Comino. Its main purpose is to safeguard and enhance the cultural and environmental uniqueness of the two islands, declined in the following objectives: (i) promote an urban development compatible with the natural resources, (ii) encourage and increase the use of local public transport and soft mobility to decongest the road network (Gozo's main problem) and reduce the negative environmental impacts resulting from private transport, (iii) limit the consumption of soil and (iv) protect the quality of life of inhabitants. However, the description of these objectives is not followed by the definition of possible transformation actions aimed at achieving them, since the Local Plan is limited to providing addresses based on the prevailing intended use of the different urban zones of the island. The only exception is represented by the infill action that is identified by the plan as the main solution to respond to the demand for new residences without sealing new surfaces.

This small planning framework does not facilitate the task of local decision makers in defining the possible choices of urban and territorial transformation to effectively oversee the needs of the island. In this respect, some important changes in terms of organization of spaces and networks and the location of the activities resulting from the construction of new transport infrastructures, such as the $13 \mathrm{~km}$ Malta-Gozo tunnel (which, according to Maltese government forecasts, will be ready by 2024) might encourage travel to Gozo.

If, on the one hand, this infrastructure can contribute to improving the attractiveness of the island, mainly by making it easily accessible, on the other, it can generate negative impacts linked, in general, to an increase in the urban load. Improving accessibility both to the activities and the set of natural and landscape resources of Gozo can lead to an increasing varied demand for spaces and volumes to perform new activities (consequent to the improvement of the overall attractiveness of the island) and therefore to a land use intensification.

The delicate balance between sustainability and urban changeover is nowhere more pronounced than in a densely populated and already urbanized area such as Malta. This poses the huge challenge of managing growth and expansion of urban activities whilst being sensitive to land use, natural resources and urban mobility issues.

\section{Methods and materials}

A key challenge for local decision makers is to allow appropriate urban transformations to accommodate the envisaged needs in such a way that land use is compatible with and respects the landscape as well as other natural and cultural heritage sites. This is a major issue in coastal zones where valuable habitats and ecosystems are threatened by the high concentration of people and activities.

The proposed methodology was developed with the aim of supporting local decision makers in the promotion 
of an optimal and sustainable land use; it is based on two main elements: (i) the use of GIS for modeling and processing analyses, as it allows detailed exploration of future scenarios of development through the visualization of alternative land-uses and their impact on urban environment and (ii) the adoption of a performance-based approach, commonly taken by public authorities in planning and urban government, to analyze the urban system in terms of demand and supply of natural and anthropic resources. Therefore, under the performance-based paradigm, land-use optimization means guaranteeing a compatible balance between urban growth dynamics and the overall urban efficiency, or rather, reducing the pressure of human settlements on the natural environment and ensuring effective livability of the concerned urban areas.

Our methodology takes account of the multiple issues and needs of urban transformation listed below, consequent both to the current demographic and economic dynamics and to the future realization of the new road transport infrastructure:

- expand the supply of urban services to meet the demand of both the elderly population and tourists;

- locate new services by implementing urban infill in a way that encourages a sustainable management of the soil resource;

- promote pedestrian and local public transport mobility in order to improve access to urban services;

- safeguard the landscape, which has a significant impact on the quality of life of the inhabitants of Gozo.

Each of these needs corresponds to one of the phases of the methodology applied to the island of Gozo (Fig. 1), as this small coastal area is characterized by remarkable natural and landscape beauties which make it a magnet for tourists; the implementation of the road transport infrastructure, for example, will lead to an increase in tourist arrivals, but, consequently, to possible conflicts between potential users, and to space congestion problems.

The sequence of phases is outlined below.

1. Definition of demand and supply;

2. 3D modeling of the built-up areas of the island of Gozo;

3. Geo-referencing of bus stops and activities of interest for elders and tourists;

4. Identification of the buildings to infill:

- $250 \mathrm{~m}$ 3D buffer for elders' accessibility;

- Identification of the buildings where some essential services for elders and tourists are already located, and of abandoned buildings;

- 3D visibility analyses; infill actions to increase the building height by adding 2-3 floors maximum, as provided in the Local Plan indications.

The first phase of the work (Fig. 1), concerned the definition of demand and supply in order to identify, respectively, the needs of locals and tourists (i.e., the set of requirements of the urban system) and the services available to meet them, due to the performancebased approach adopted. The databases of the National Statistic Office-Malta (NSO) and the Gozo Channel Line (the ferry company that connects Malta and Gozo and provides data on the traffic of passengers traveling to Gozo) were used to recognize the socio-economic characteristics of the population (e.g. the age pf population, number of tourists). The databases elaborated by the GeoSYS Company were chosen to detect the services available in Gozo, integrating them with spatial analyses in the GIS environment and direct surveys on the island.

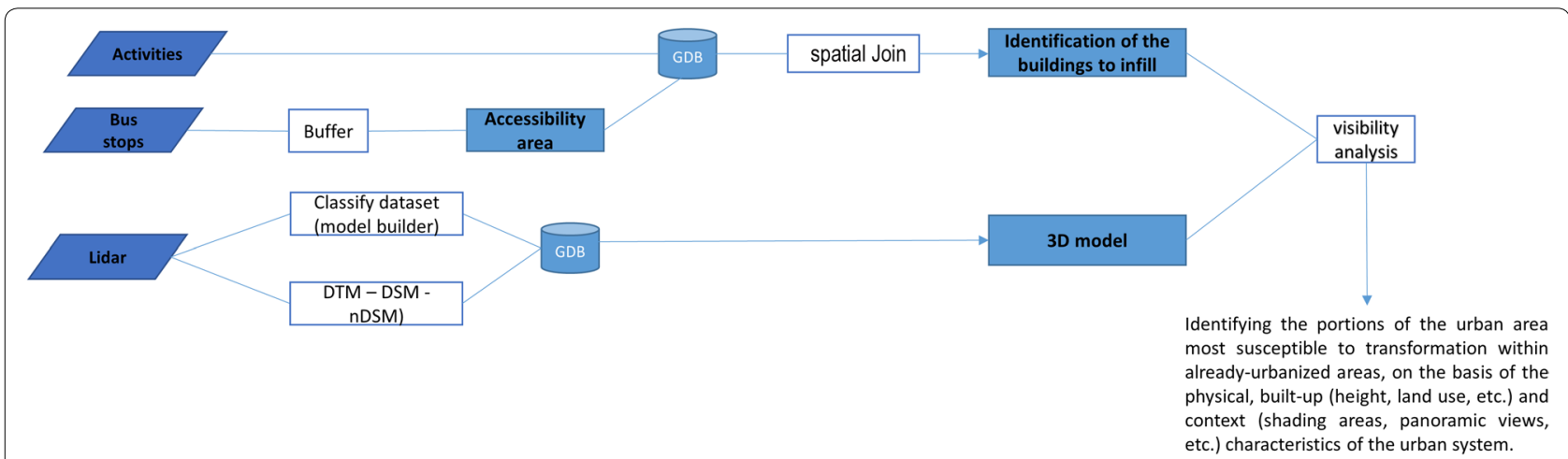

Fig. 1 The procedural GIS steps of the methodology proposed. The parallelograms are the inputs, the white rectangles are the spatial analysis and the blue rectangles are the outptuts 
This study phase of the anthropic subsystem reveals that the demand is made up of residents and tourists over 65 . Therefore, the definition of the supply concerned the services of interest for the senior residents, such as:

- hospitals, local health centers and pharmacies;

- elderly care homes;

- cinemas, libraries, theaters and museums;

- post offices;

- supermarkets;

and for tourists:

- supermarkets;

- bars and restaurants;

- accommodation;

- bathing facilities;

- museums.

The definition of demand and supply was followed by the elaboration of the 3D model of the entire island of Gozo (Phase 2), as this type of modeling can represent a valid support to the choices of territory transformation (see "Introduction" section). Being the city a dynamically complex system (Gargiulo 1995), it is possible to visualize different future assets and perform spatial analyses of the city itself by modeling it, in order to evaluate the potential impacts of transformations on natural and anthropic resources.

To build the 3D model (Fig. 1), the lidar data of all Gozo physical elements produced in the European project ERDF 156 (Developing National Environmental Monitoring and Infrastructure Capability) by using the ArcGIS Pro software, were processed in LAS Dataset format. The advantage of using lidar data is related to their geometric precision; in fact, they allow for a realistic model of the territory, since this type of data is the product of an optical remote-sensing technique that uses laser light to densely sample the Earth's surface, producing extremely accurate $\mathrm{x}, \mathrm{y}, \mathrm{z}$ measurements.
In this perspective, the ModelBuilder tool in the GIS environment, which is a sequence of processes that standardizes and parameterizes a workflow, has been developed; its outcome is an automatic classification of all objects reflected by the laser pulse. Accordingly, this model can be used in any other context: by changing the input data, the classification is obtained quickly. It should be pointed out that several preliminary tests have been carried out to successfully develop the final model of the natural and anthropic elements of the study area, taking as reference area a small lot of Zebbug (Gozo), in order to calibrate the parameters each time until the definition of the model used to categorize the total LAS Dataset (Fig. 2), with its 19 classes of data.

In particular, class 19 includes all those lidar points that cannot be categorized (such as birds). After the classification, the LAS Dataset has further been "cleaned" and modified in order to recheck the automatic classification performed. This process is essential as some lidar points may be recognized in a wrong class, as, for example, the points outlining the profile of a crane that are improperly classified into class 6 (Building). This process of systematization of the LAS Dataset allows for a manual reclassification of certain points, especially of some undefined objects that fall into class 19 (Reserved).

After classifying all elements of the LAS Dataset, heights and shapes from lidar point cloud data were extracted by manually executing an accurate editing process and considering the roof form of "medium" buildings, that is, all flat roofs. To assess the lidar data accuracy, they were compared to the data provided by the Malta Inspire Geoportal. The result of this GIS procedure was a model of the built-up area of the island of Gozo, obtained by using the three levels of elevation (rasters) previously calculated:

- Digital Terrain Model (DTM);

- Digital Surface Model (DSM);

- Normalized Digital Surface Model (nDSM).

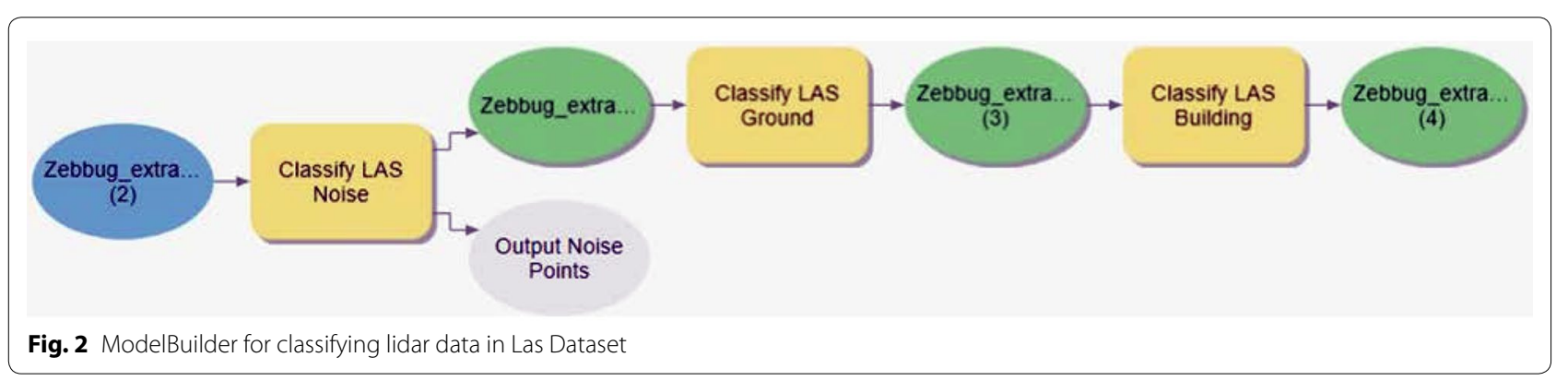


After getting the 3D model, the services supplied (listed above) were geo-referenced and this third phase of the methodology made it possible to identify three specific areas of the island characterized by the lack of services of interest both for the elderly and for tourists. In particular, in the Victoria area it would be useful to implement the volumes of existing buildings or change their intended use, in order to improve or add new services for the elderly, such as elderly care homes (which are totally absent), being Victoria "the heart of the island" for its historic center and because the only hospital of Gozo is located in this town. The villages of Xlendi and Marsalforn, on the other hand, should optimize services for tourists (accommodation, restaurants and pharmacies), as these areas have a strong tourist vocation.
Phase 4 of the methodology concerns the identification of the buildings to infill. The starting point of this phase consisted in geo-referencing the bus stops (Fig. 1), paying particular attention to those portions of urban fabric that are more accessible by local public transport, in order to avoid further traffic congestion on the Gozo road network and, also, to foster soft mobility, thanks to the future implementation of the tunnel connecting Gozo and Malta. Such measures would boost soil management optimization, thereby avoiding unnecessary transformation of new portions of land to guarantee accessibility to the planned services. From this point of view, starting from the localization of the public road transport network stops, the buildings were identified taking account of:

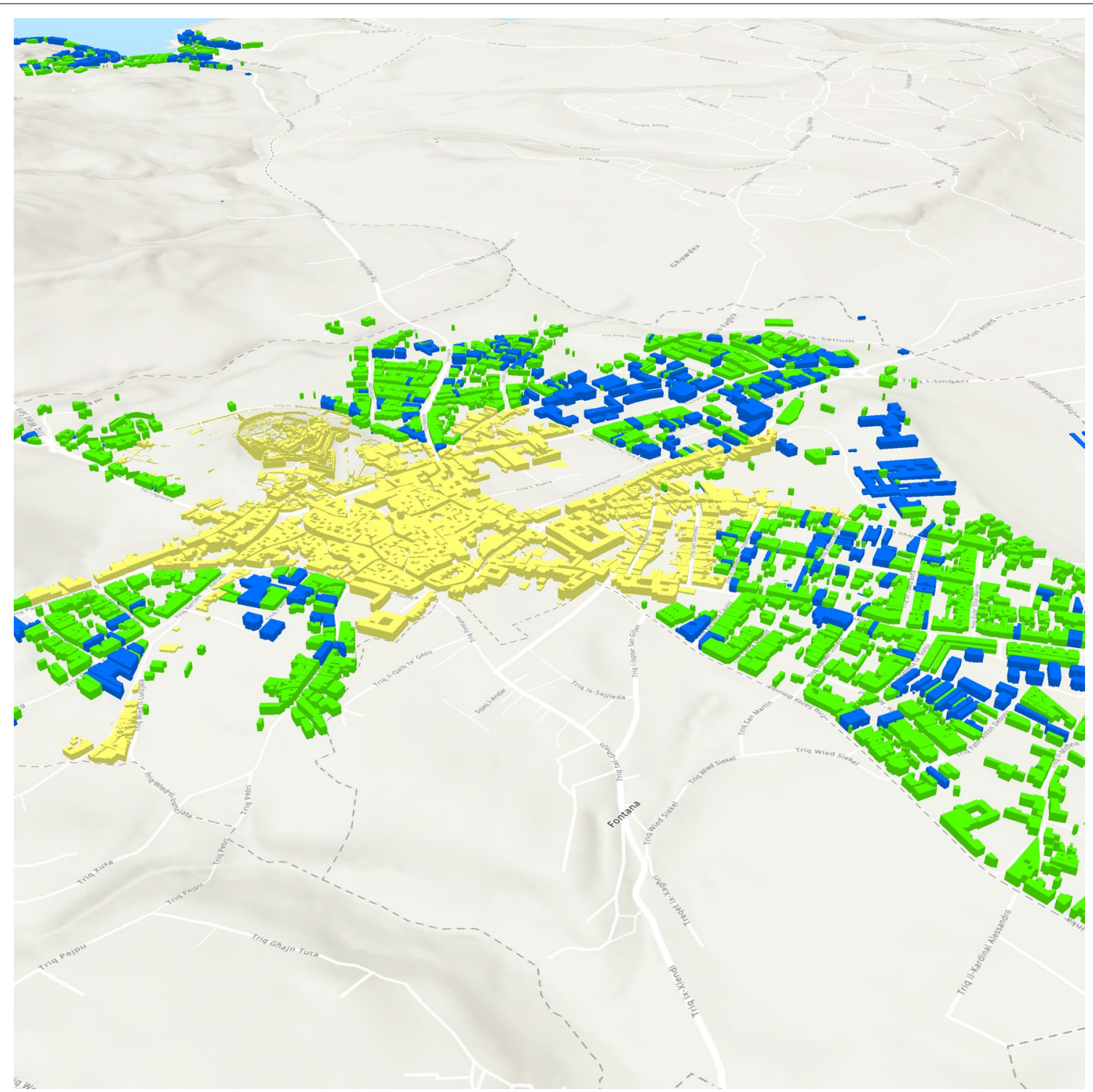

Fig. 3 Victoria: UCAs (yellow); area inside buffer of $250 \mathrm{~m}$ —no infill (blue); area inside buffer of $250 \mathrm{~m}$ —infill (green) 


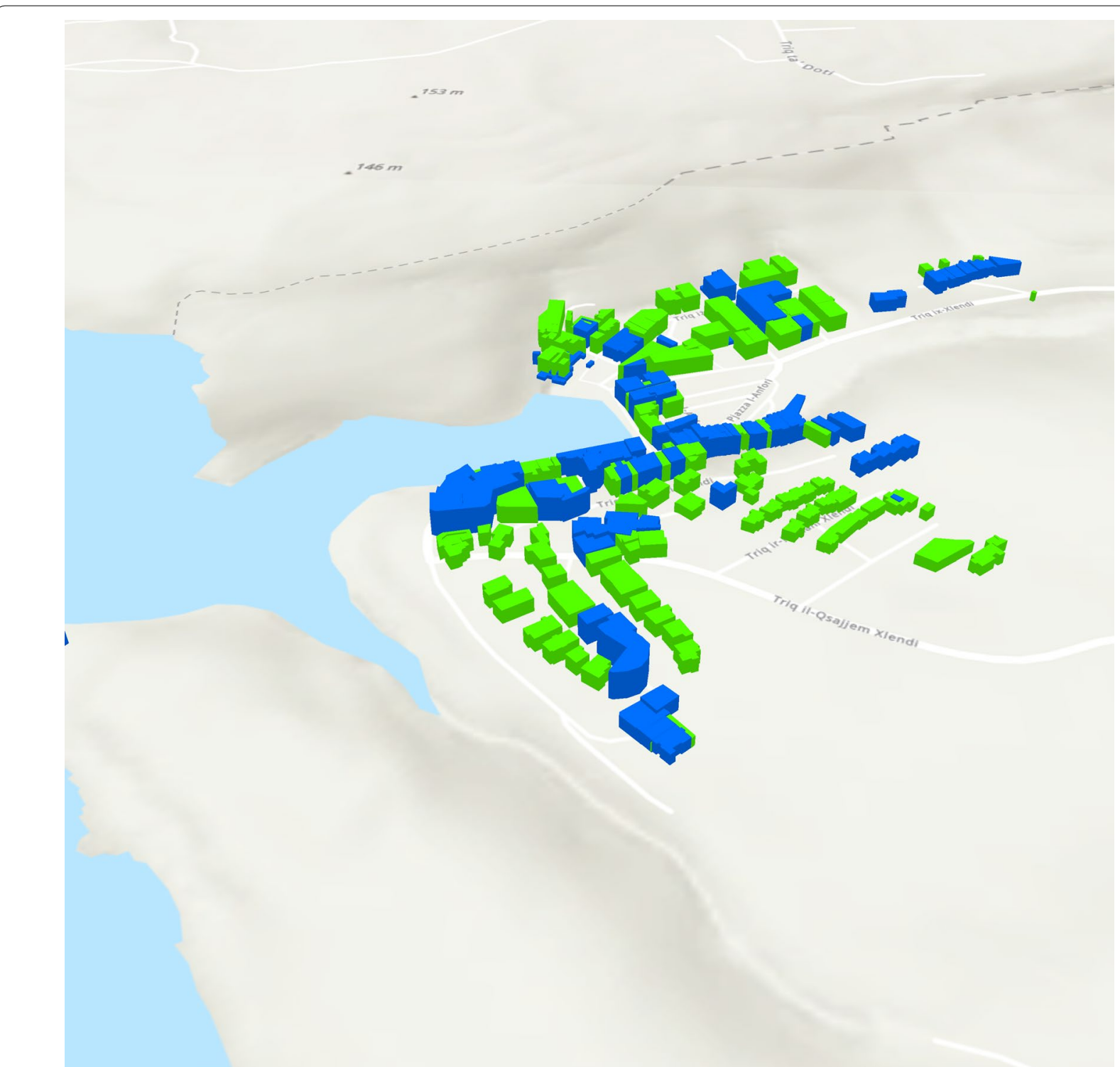

Fig. 4 Xlendi: area inside buffer of 250 m—no infill (blue) and area inside buffer of 250 m—infill (green)

- $250 \mathrm{~m}$ buffer zones of bus stops;

- Urban conservation areas (UCAs), which are protected areas of great architectonic and/or historical interest, whose aspect is to be preserved or improved;

- The indications provided by the Gozo-Comino Local Plan as regards the buildings that can be transformed and their maximum height.

Indeed, excluding the buildings identified by the Planning Authority as UCAs and, therefore, "non-transformable", due to their historical, artistic and architectural value, the remaining buildings falling within the $250 \mathrm{~m}$ buffer were considered as "transformable" (Figs. 3, 4,
5) and some of them have already been selected by the Local Plan for future transformations. They make up the sample of the territory transformation being studied, considering infill as a transformation intervention able to reduce soil consumption (Young 2016), in accordance with the Local Plan indications.

If, on the one hand, vertical development contributes to reduce soil use, on the other, it can lead to the loss of several panoramic views (both on the natural and "built" landscapes) which give value to a specific area. In this perspective, visibility analyses were conducted for the three areas of Victoria, Xlendi and Marsalforn. In particular, as regards the area of Victoria, the visibility of 


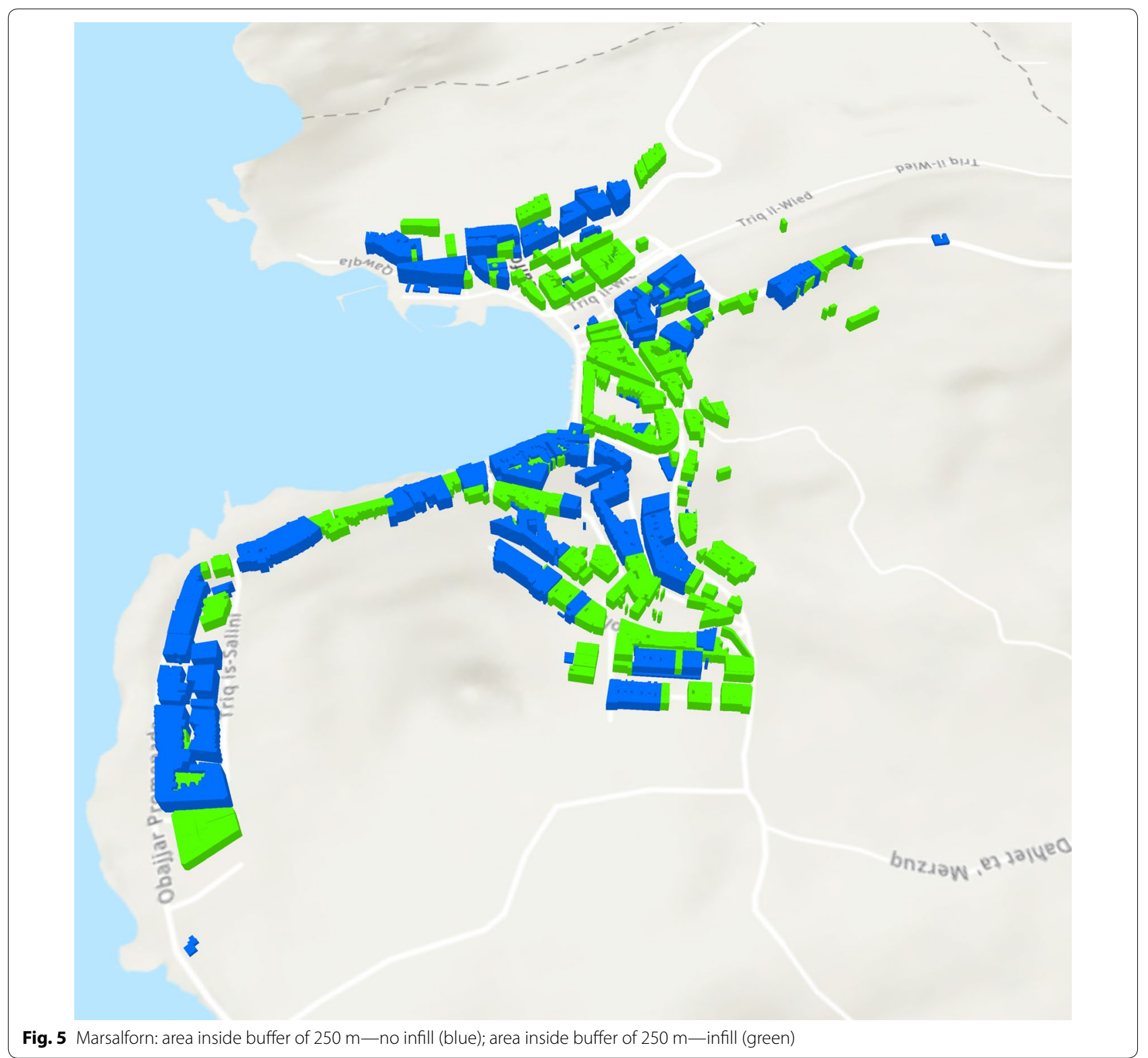

the buildings on the built-up area of historical value was assessed, while for Xlendi and Marsalforn, starting from the Digital Terrain Models (DTM), the analyses determined the "visible and non-visible areas" from the buildings, paying particular attention to the visibility of the landscape areas.

The analyses were performed on a 3D model that reproduces both the current state and future prospect of the buildings previously identified, the height of which had been increased. In this way, it was possible to assess the impacts that new buildings will have on the historical, architectural and landscape heritage of the island, as well as on the quality of life of its inhabitants, by protecting the soil resource and, at the same time, trying to preserve the areas of high value which make Gozo stand out in the Mediterranean Sea for its natural and environmental beauty.

In the case of Victoria and its historic center (UCA), we carried out a visibility analysis on the built, namely, the assessment of the impacts of transformations in light of the visibility on the historic center from each building. For Xlendi and Marsalforn, where the natural, non-historical component is more significant, the visibility of the landscape from the built-up area was examined. Given the different nature of the target point, the two analyses were performed using different procedures. 


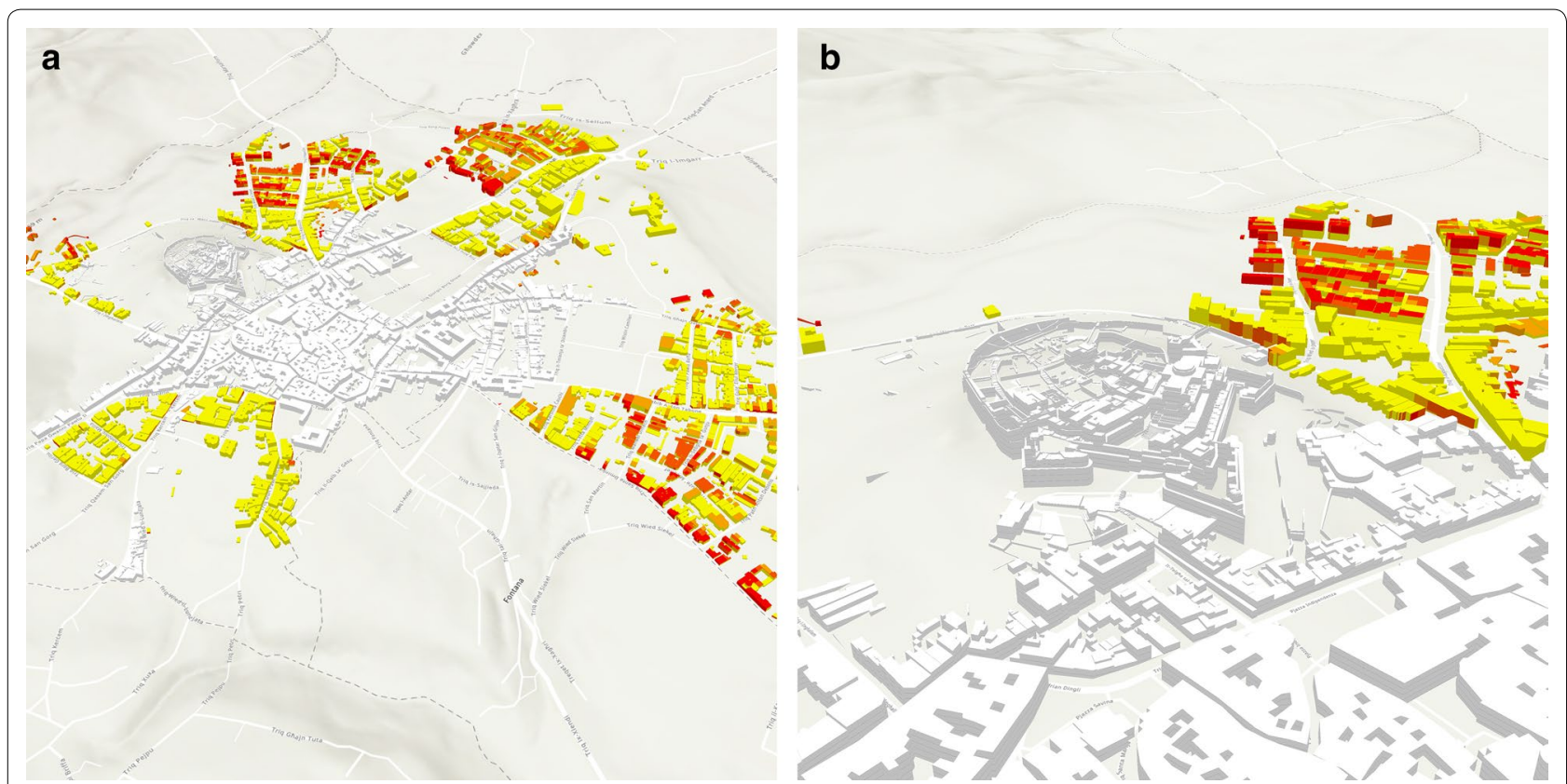

Fig. 6 a Visible area percentage: very low visibility (yellow); low visibility (light orange); average visibility (dark orange); high visibility (red). Victoria now. b Visible area percentage: very low visibility (yellow); low visibility (light orange); average visibility (dark orange); high visibility (red). Victoria now

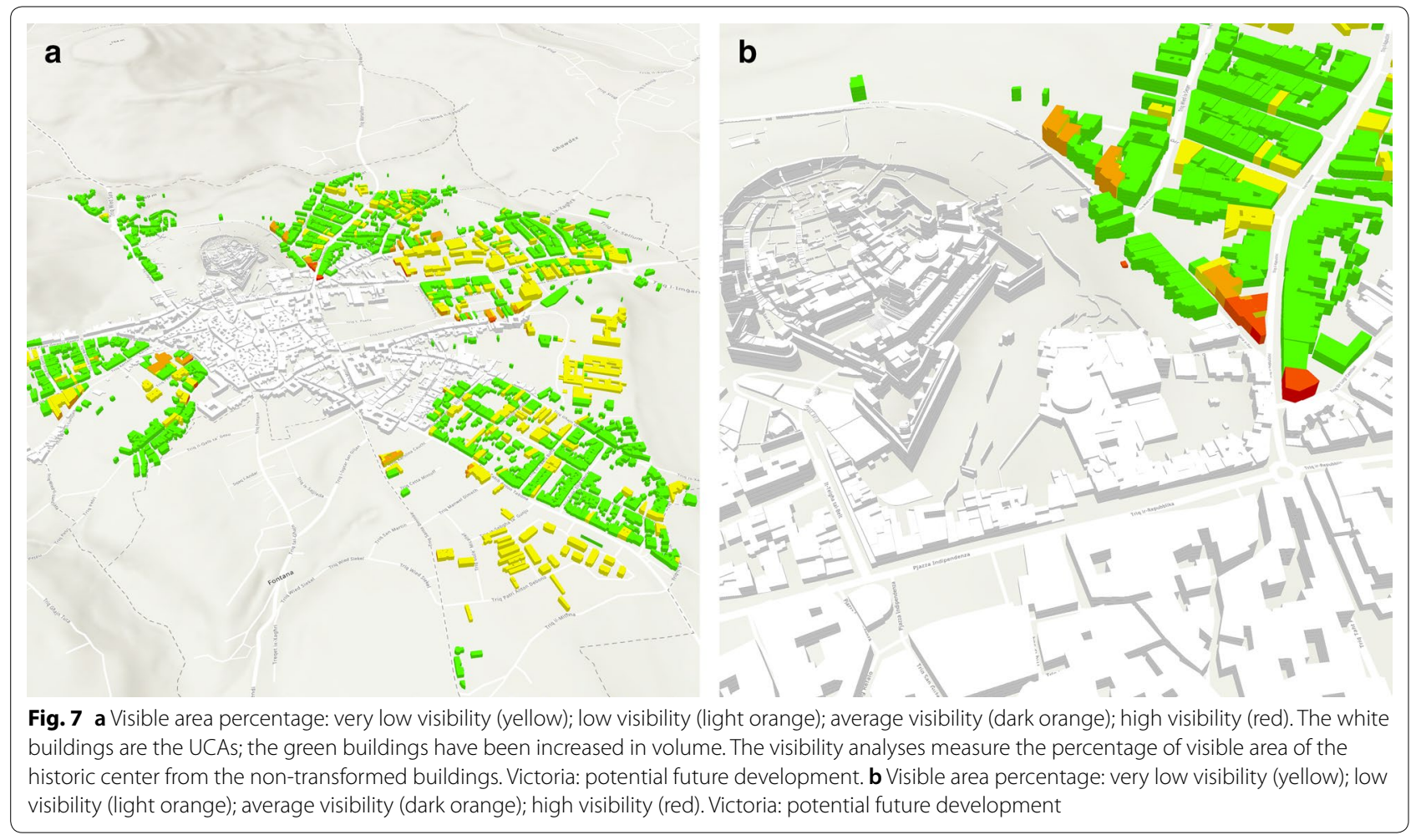

For Victoria, in fact, the outputs of the visibility analysis are multipatch panels $(10 \times 10)$, or a type of reticular geometry in which $3 \mathrm{D}$ objects (in this case the buildings) are stored, which return the visibility values in terms of "percentage of visible area". In practice, these $10 \times 10$ multipatch panels (size in line with the size of the 


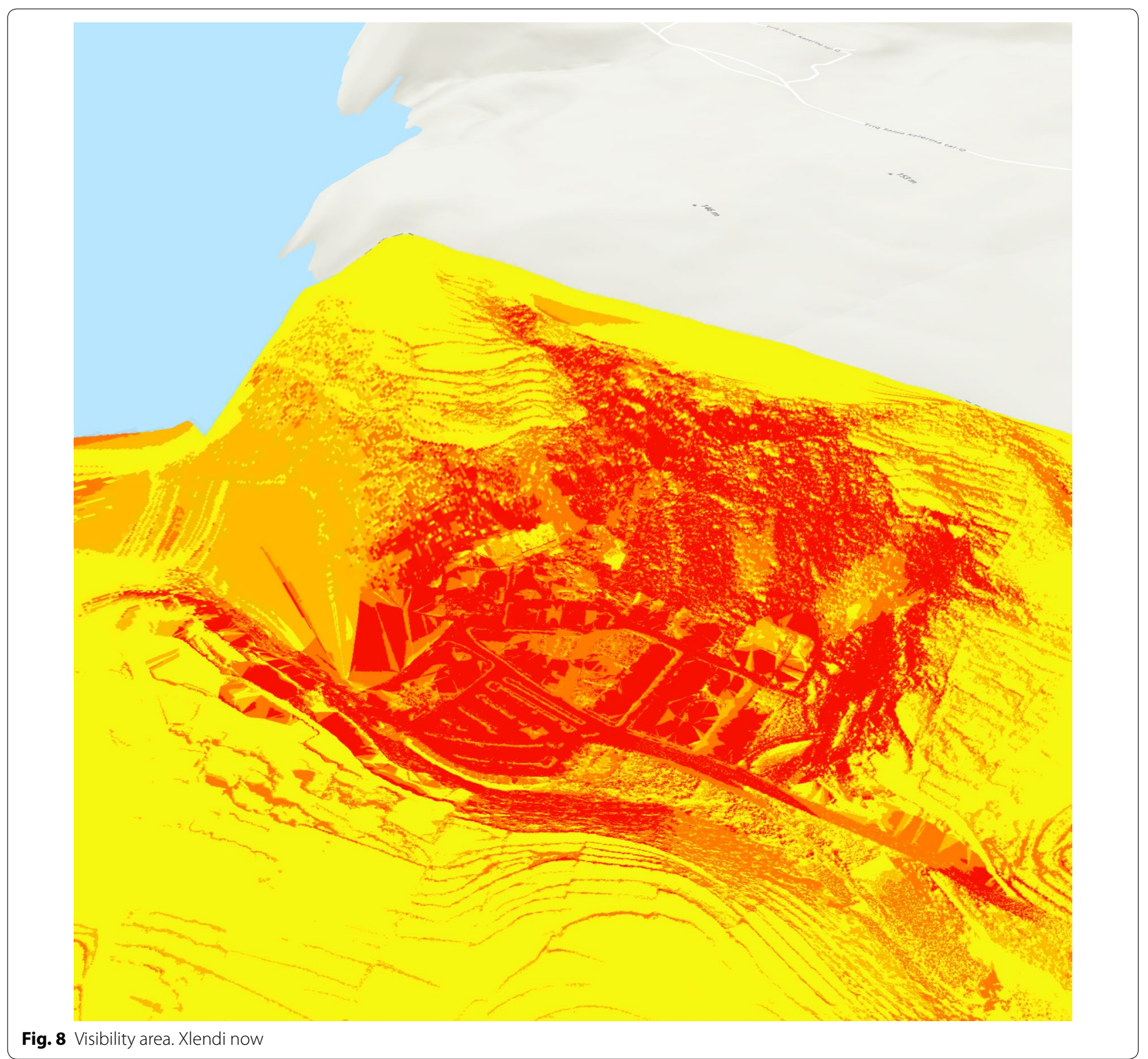

buildings) show the percentages of visible area of the historical part of the built-up area for each individual building, according to their size $(10 \times 10)$.

Compared to other applications of 3D GIS models found in literature, which relate almost exclusively to a single building or to small portions of urban settlements, this work has carried out urban-scale visibility analyses, in order to consider the negative effects in terms of visibility in case the infill of existing buildings is performed. These analyses may provide valid support to local administrations in identifying the areas to be transformed and minimizing the impacts of the transformation itself.
The application of the model on a larger scale, such as the urban one, has made it necessary to divide the builtup area into different sections to permit accurate processing of the input, observation and obstruction data for each of them. Furthermore, the decision to divide the entire area of Victoria into smaller areas highlights the need to reduce processing time.

The results of the visibility analysis were classified by the natural breaks method into four classes, whose threshold values are different for each of the areas of Victoria identified. In order to get unique values for each class, common to all areas, so that they could be readily 


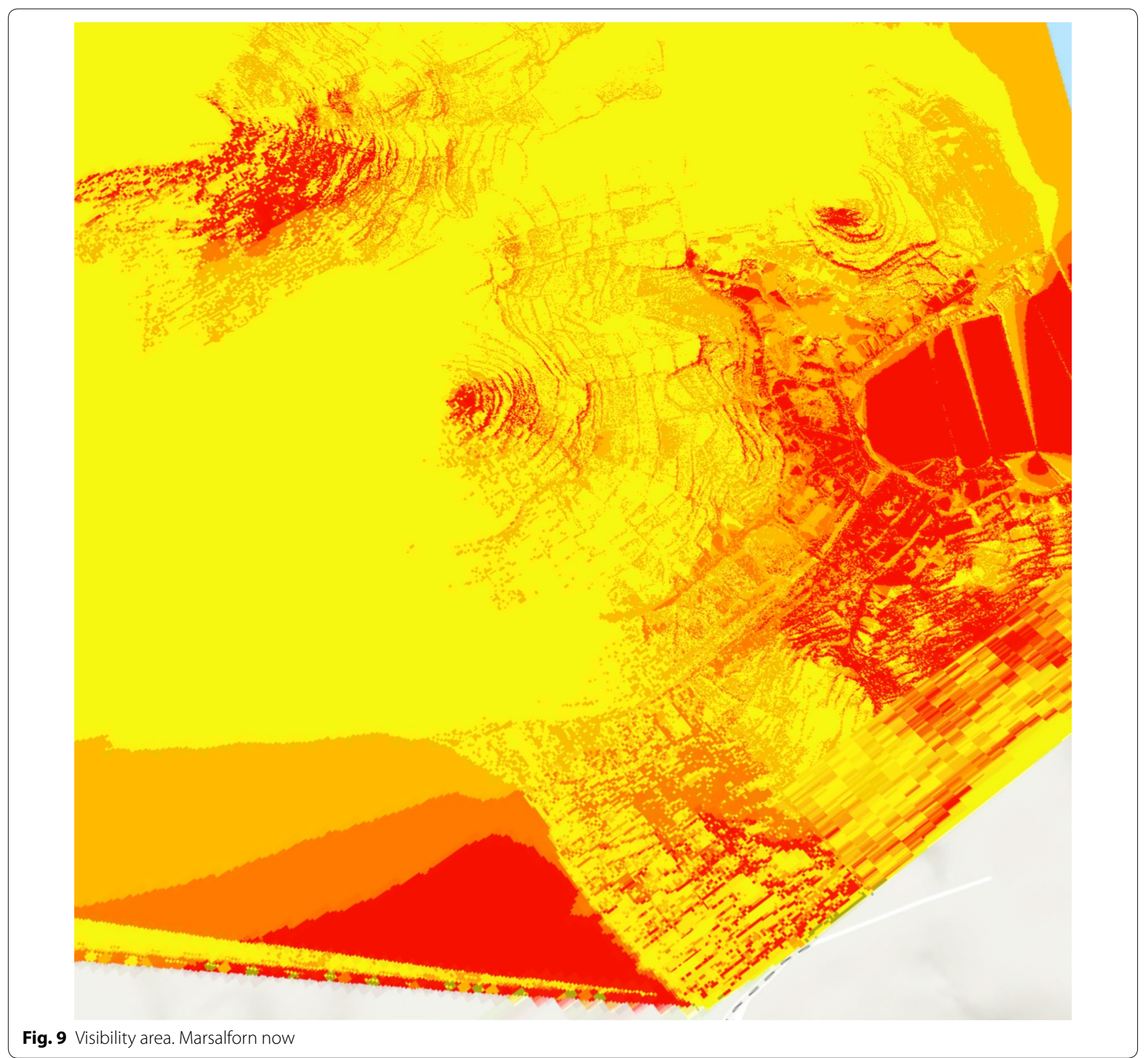

compared, the average value was calculated for each individual class and the visibility results for each area were reclassified according to the following classes (Figs. 6a, b, $7 \mathrm{a}, \mathrm{b})$ :

- Very low visibility $0 \%<x \leq 6 \%$.

- Low visibility $6 \%<x \leq 22 \%$.

- Average visibility $22 \%<x \leq 49 \%$.

- High visibility $49 \%<x \leq 100 \%$.

Unlike Victoria, for Xlendi and Marsalforn the variation in visibility was made in raster format, which is the result of a spatial analysis that evaluates the visibility of each building over the landscape. This type of analysis is a first attempt to assess the impacts of the built on the landscape in terms of visibility, on the urban scale. Basically, the buildings were located by taking as reference point their center of gravity; the average height of a man $(1.60 \mathrm{~m})$ on the top floor of the building was considered as the height of the observation point. The results of spatial processing were two visibility rasters: one obtained by considering the current building height (Fig. 8, Xlendi and Fig. 9, Marsalforn) and the other considering the transformation, in height, of certain buildings, as required by the Local Plan (Fig. 10, Xlendi and Fig. 11, Marsalforn). They were classified in 


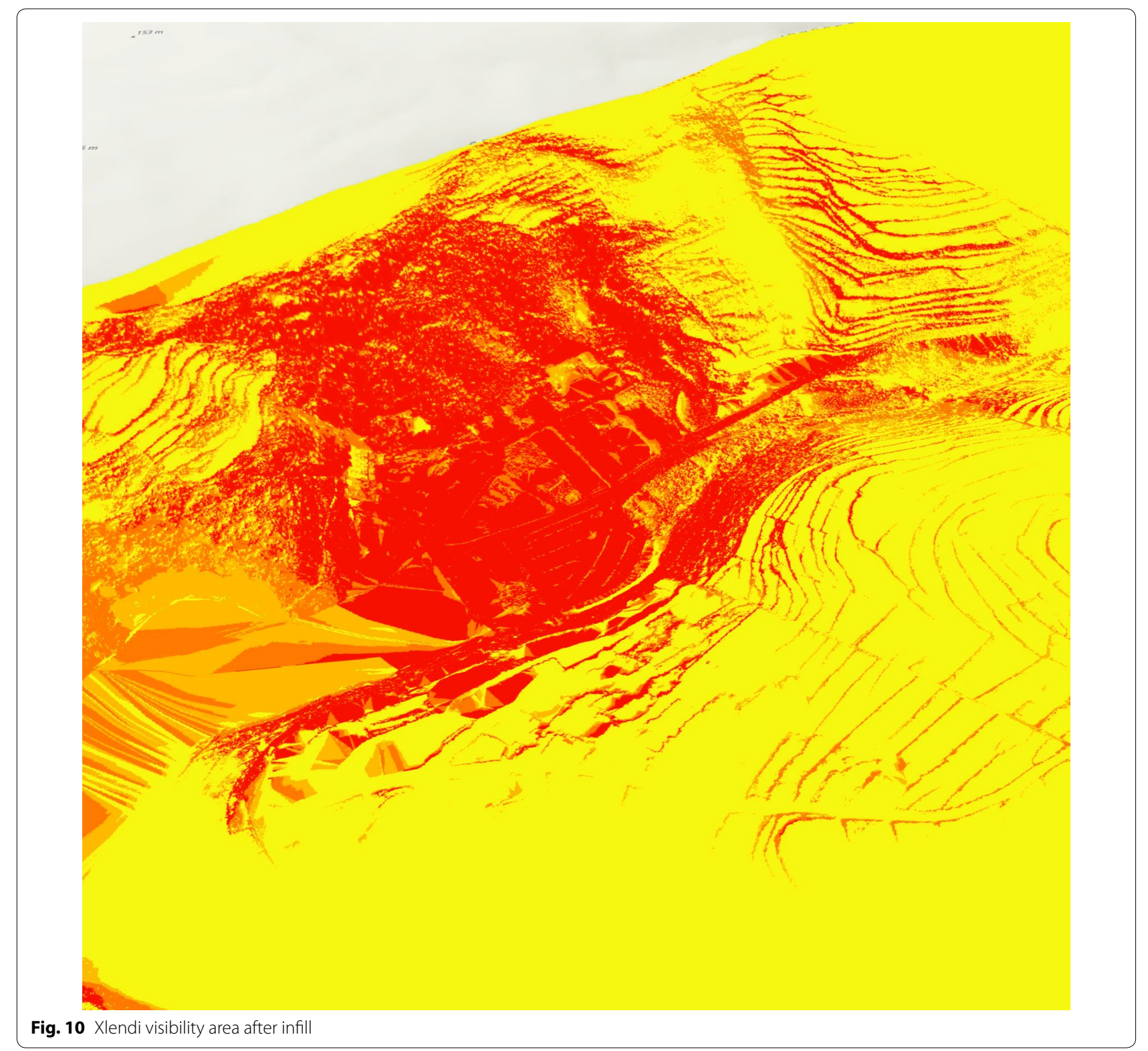

the same way as the results obtained for Victoria and were compared by calculating the difference between the two rasters (Fig. 12, Xlendi and Fig. 13, Marsalforn), in order to evaluate the loss of visibility the observer will have on the landscape, should the infill of the considered buildings occur.

\section{Results}

The proposed methodology, aimed at simultaneously evaluating the different effects of urban transformations, has been applied to Victoria, Xlendi and Marsalforn, three areas of the island of Gozo. The choice of these three settlements is linked to their functional diversity 


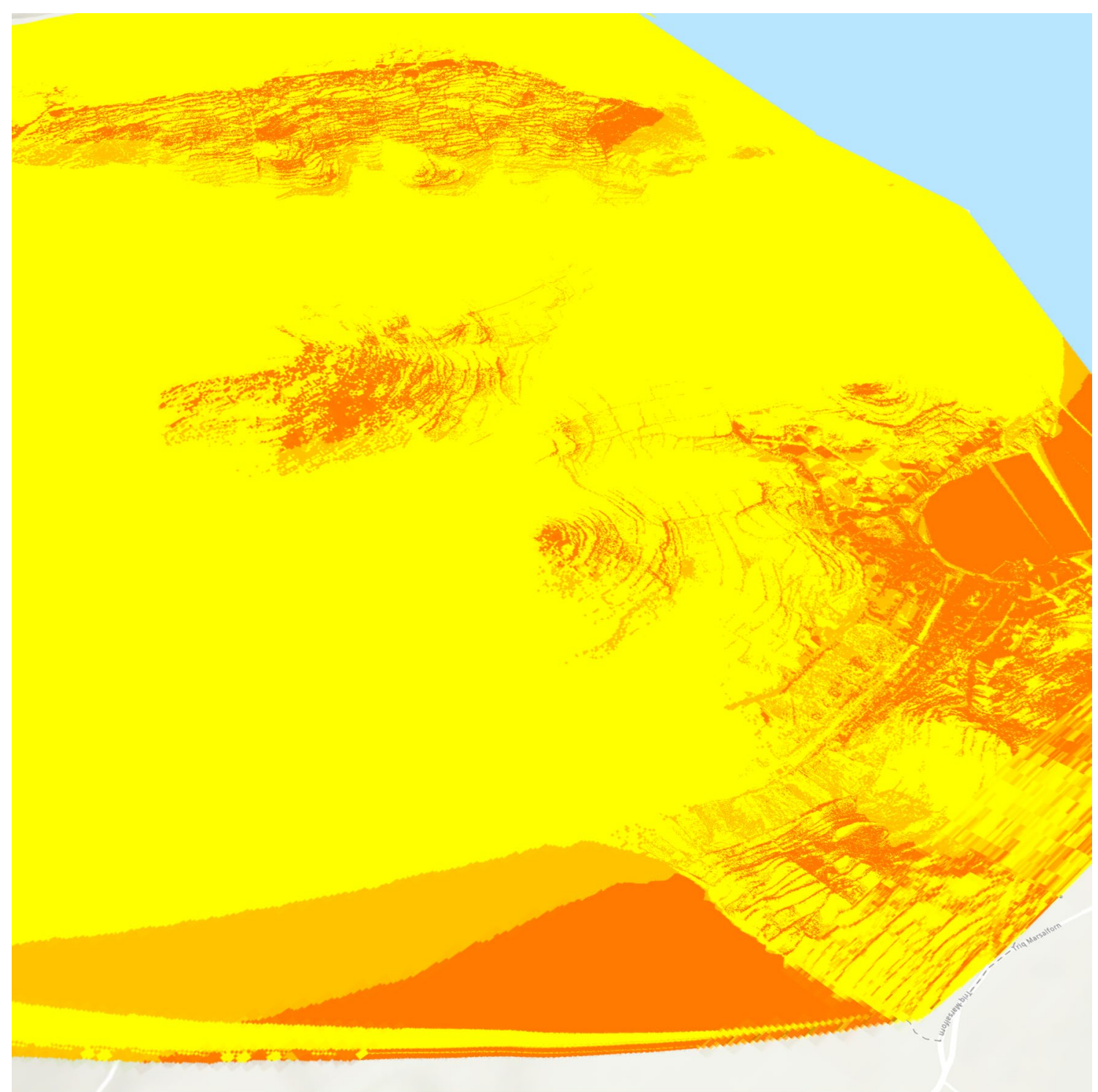

Fig. 11 Marsalforn visibility area after infill

(as they offer many different services) and to urban accessibility, taking account of two aspects: local decision makers' awareness of the need to expand the range of urban services supplied, both for the resident population (mainly composed of elders) and for tourists, and of the current demographic and economic dynamics. In this perspective, what stands out is the need to increase facilities without exploiting Gozo's resources and sealing new soil (Local Plan 2006). 


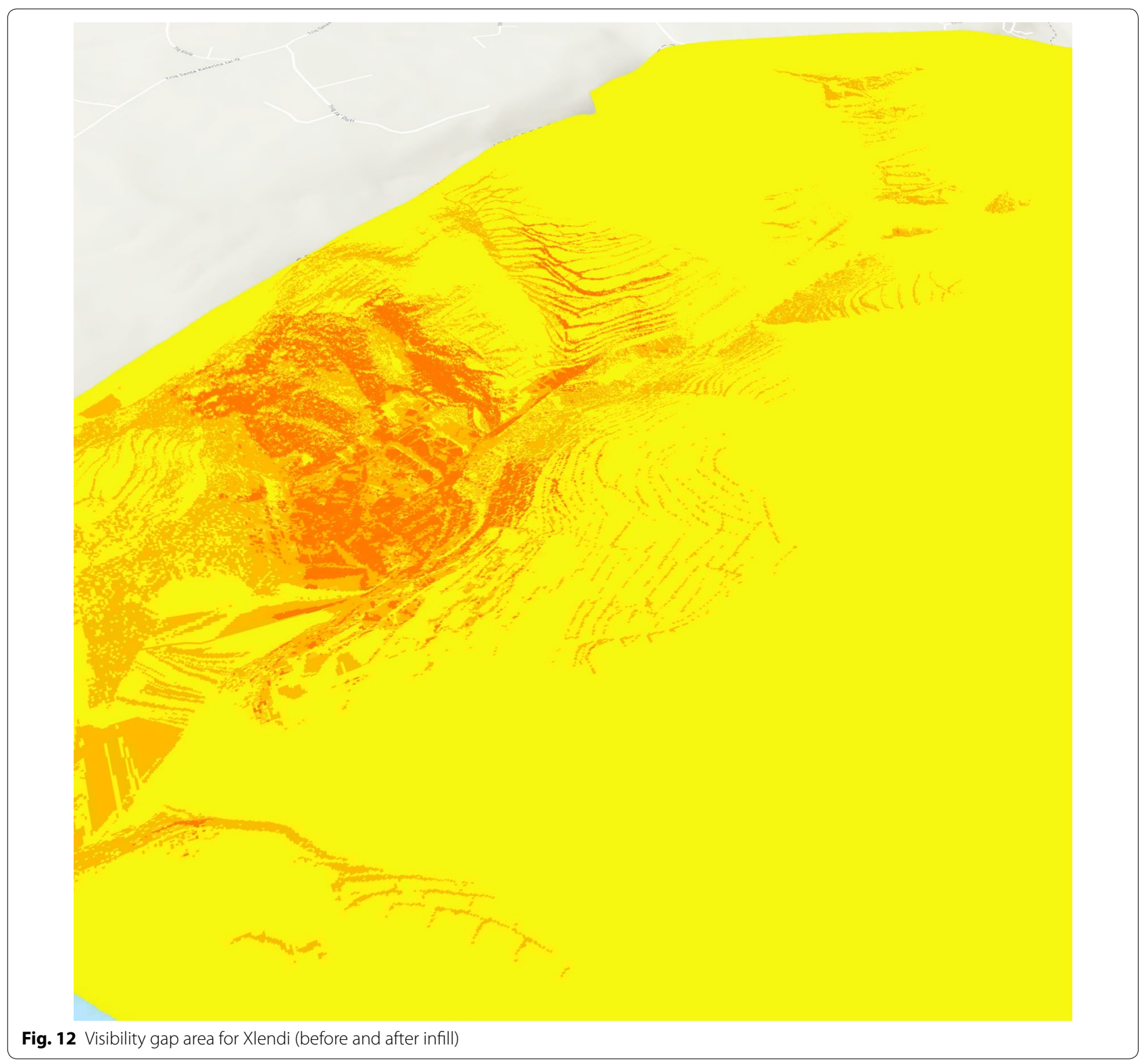

The study of accessibility, carried out by identifying the influence areas of the road local public transport stops, has shown that, among the three areas examined, Victoria appears to be the most accessible as the stops cover almost the entire town.

In order to enhance the living conditions of the inhabitants of Gozo by increasing the main urban services, without compromising the environmental quality of the island (which constitutes its strong point in terms of tourist attractiveness), the Planning Authority foresees a vertical development in the built-up area, also to avoid a delocalization of services, which would lead to excessive use of private cars (especially in view of the tunnel construction).

If, on the one hand, this strategy of urban transformation is aimed at protecting the soil resource, on the other, it risks compromising the natural value of certain portions of the territory, leading to the loss of many panoramic views.

The visibility analyses, carried out starting from the development in GIS environment of the 3D models of the three areas of Gozo examined, showed that increasing the building height in Victoria (by adding two floors maximum to some buildings) compromises the visibility on the historic center of many buildings for which infill 


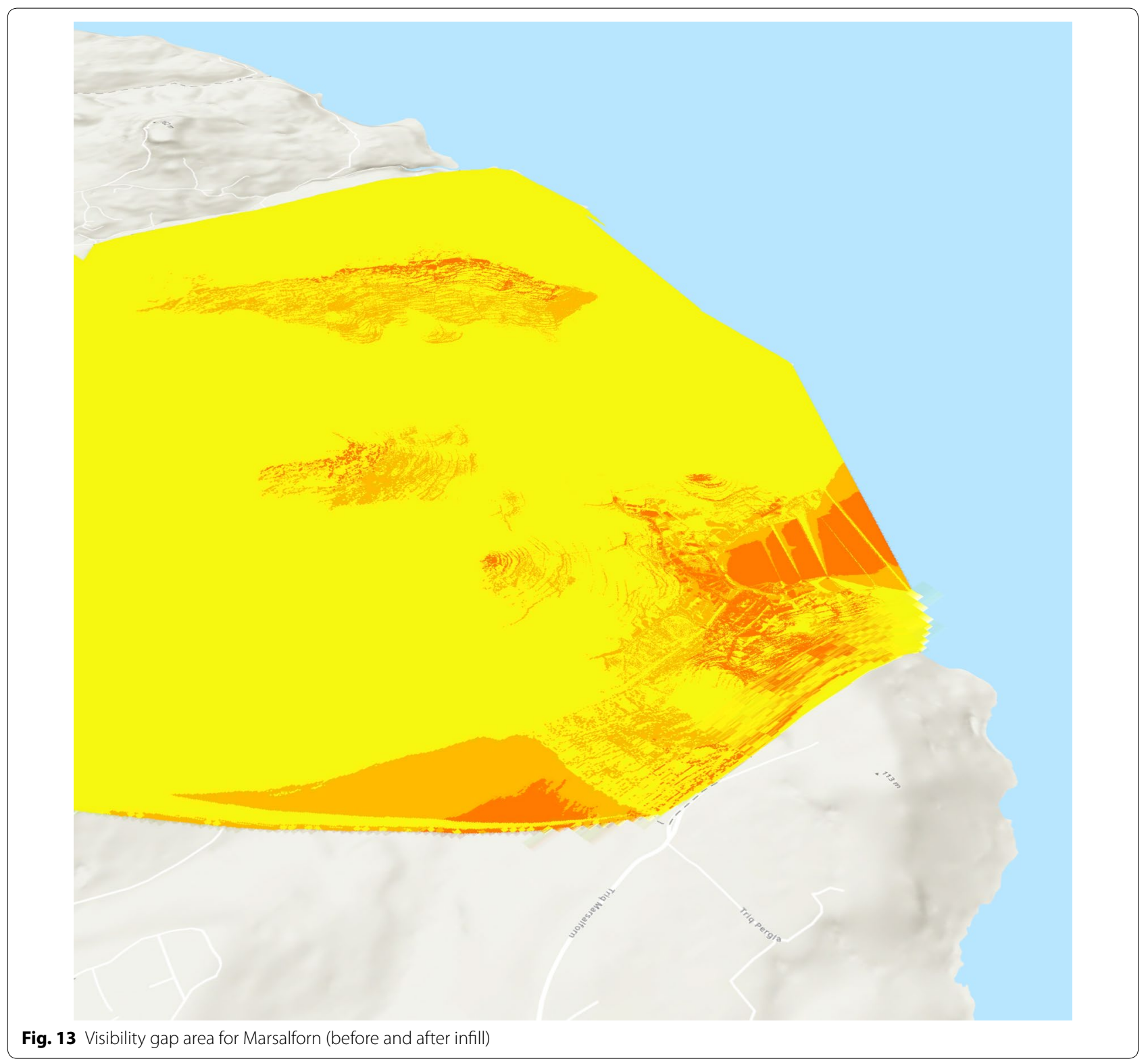

is not provided in the Local Plan, since many of them are intended for public use (Figs. 14 and 15).

To sum up, the proposed methodology, combined with the visibility analysis allows the detection of the area of Victoria neighboring the UCAs and included in the buffer zone of $250 \mathrm{~m}$ from the bus stops as the area susceptible to infill, whilst for the eastern area of the town infill is not provided in the Local Plan since many buildings are intended for public use and their height cannot be increased.

The comparison of Figs. 14 and 15 (in which the buildings in green are urban infill sites) clearly shows that about $80 \%$ of buildings that were previously within the average or even high visibility classes have lost much of the visibility on the historic center, moving to the very low visibility class.

\section{Conclusions}

This paper aims at contributing to the debate over urban sustainability and sustainable land management, considering that about $700,000 \mathrm{~km}^{2}$ of the Earth's surface will be covered by urban built-up areas in 2030. The inevitable demand for transformation, due to the intrinsic dynamicity of urban systems (Gargiulo 2009), requires the development of appropriate methods, techniques and tools to support local decision makers in optimizing land 


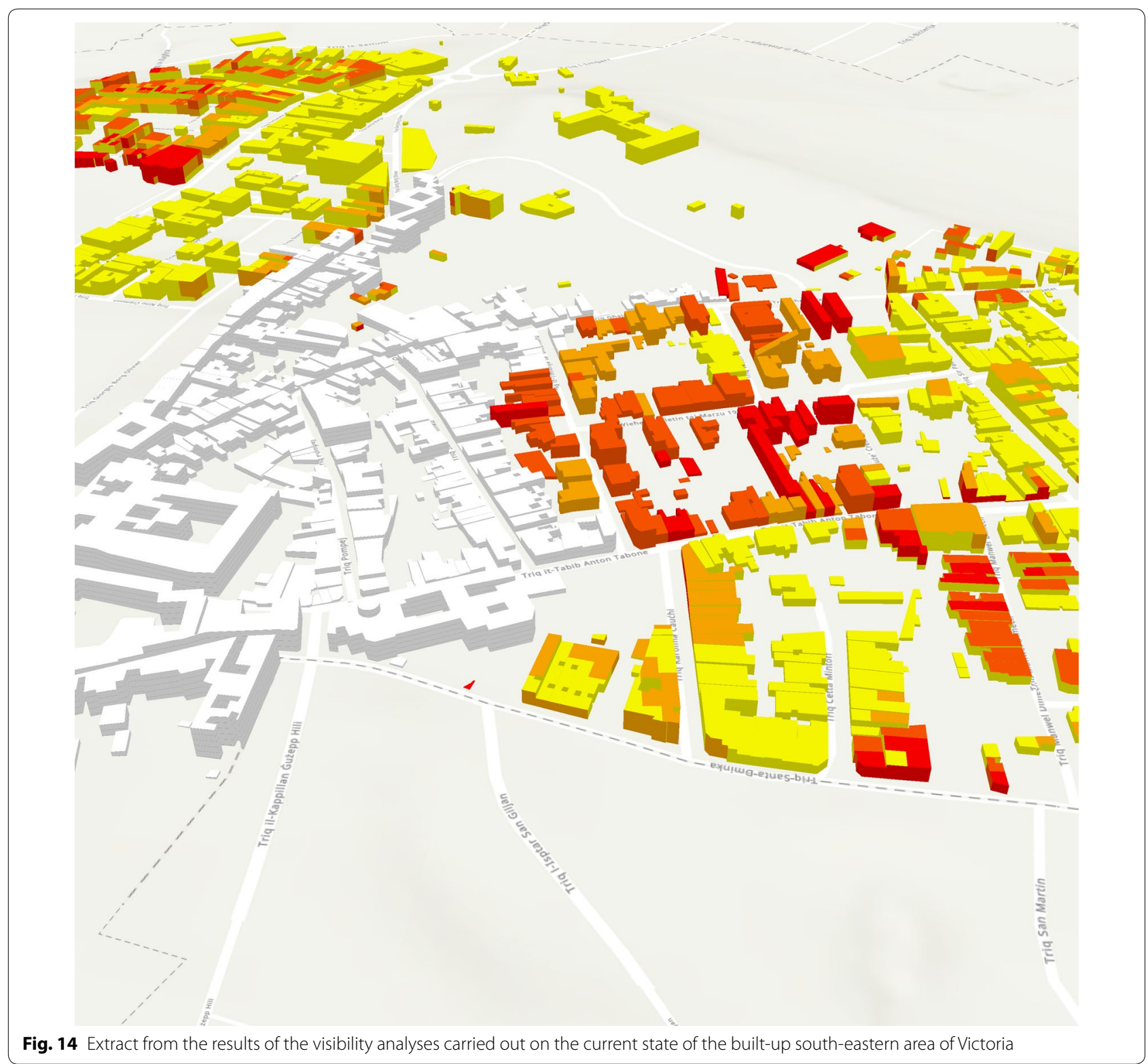

management, by ensuring that anthropic transformations will be compatible with the natural features of the soil resource (XX 2018). This statement supports the idea that optimizing land use is essential to establish proper proportions of various land use types, improve the sustainable utilization rate of land resources and maintain a relative balance of the ecosystem in the land environment (He et al. 2017; Luo et al. 2019).

The 3D GIS-based methodology proposed has identified the most suitable areas for urban transformation due to the presence of residents, tourists, services and for being accessible by public transport.
Starting from the indications of the Local Plan, the visibility analysis on the current state and on hypotheses of future development was conducted to sensitize public decision makers on the importance of panoramic views, which is often underestimated but leads to a loss of the physical characteristics of the place as well as of its value.

This study may assist decision makers in evaluating the impacts deriving from the vertical development of one or more buildings, in order to protect both the urban system and the collective interests. In this perspective, the use of a 3D city modeling favors a more immediate analysis of the results and the potential 


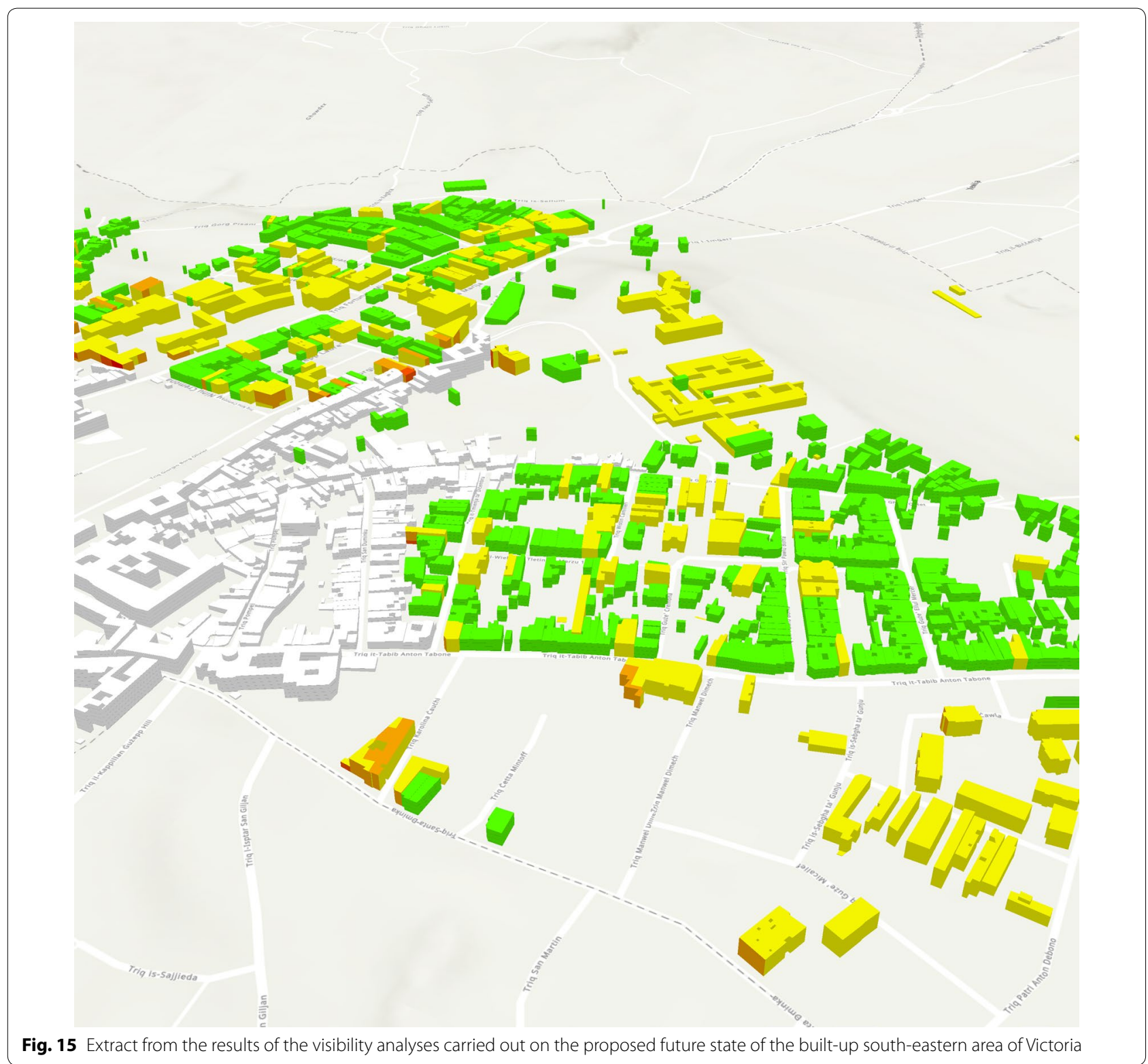

impacts of transformations on urban environments (Steinicke et al. 2006; Shiode and Yin 2008; Yin and Shiode 2014; Chundeli 2017).

The proposed methodology, applied to the entire island of Gozo, can provide, in practice, a first mapping of the parts of the build-up area most susceptible to be transformed, identifying the high degree of transformability both for their physical and functional characteristics. For instance, according to the results obtained, in all the three towns studied (Xlendi, Marsalforn and Victoria) healthcare services could be located within those built portions considered as "transformable", such as the presence of local markets could be increased, especially in Xlendi and Marsalforn.

Moreover, in order to preserve the value of the areas, the visibility analysis could become an annex project to be submitted to public administrations to seek authorization for interventions of urban transformation.

Another functional analysis for local decision makers could be the cone of visibility of the buildings on the historic center. This type of analysis can integrate the visibility analysis proposed in this work since, if the result of the visibility analysis is the percentage of visible area of the historic center from each building, the 


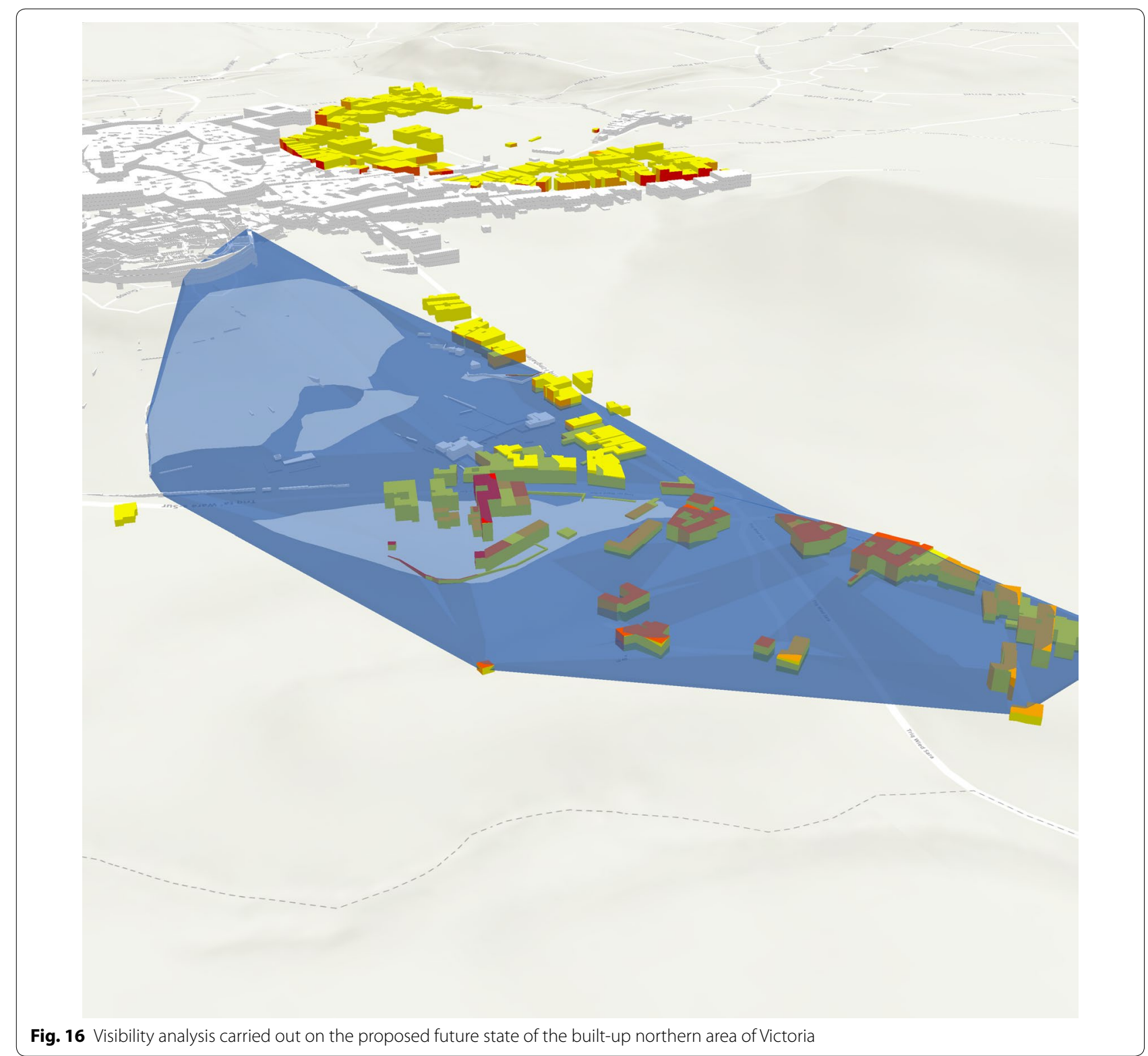

visibility cone allows for a qualitative reading, providing the portions of the historic center that are actually visible from a specific observer point (an example is proposed in Fig. 16).

The analyses conducted on Xlendi and Marsalforn gave the first results (Figs. 12 and 13) on the potential impact of new buildings on the landscape. In this regard, it would be advisable to carry out more accurate analyses working on a more detailed scale than that used in this work, in order to consider different parameters, such as the earth curvature and the presence of vegetation, which have been neglected in this study.

\section{Acknowledgements}

The authors would like to thank GEOSYS company (Malta) who contributed their knowledge during the initial stages of the 3D-GIS modelling. In particular, we are very grateful to Tim Camilleri and Nunziatina Fragale.

\section{Authors' contributions}

Although this paper should be considered a result of the common work of the authors, FZ took primary responsibility for "Introduction", "Results" and "Conclusions" sections; RM took primary responsibility for "Gozo island: between urban transformation and sustainability" and "Methods and materials" sections. Both authors read and approved the final manuscript.

\section{Funding}

Not applicable. 


\section{Availability of data and materials}

The datasets used and analyzed during the current study are available from the corresponding author on reasonable request.

\section{Competing interests}

The authors declare that they have no competing interests.

Received: 9 July 2019 Accepted: 27 September 2019

Published online: 08 October 2019

\section{References}

Assadourian E, Prugh T (2013) State of the world 2013: is sustainability still possible?. Island Press, Washington, DC

Batty M (2001) Exploring isovist fields: space and shape in architectural and urban morphology. Environ Plan B Plan Des 28:123-150

Batty M, Densham P (1996) Decision support, GIS and urban planning. Sistema Terra 5:72-76

Biljecki F, Stoter J, Ledoux H, Zlatanova S, Çöltekin A (2015) Applications of 3D city models: state of the art review. ISPRS Int Geo-Inf 4:2842-2889

Billen R, Cutting-Decelle AF, Métral C, Falquet G, Zlatanova S, Marina O (2015) Challenges of semantic 3D city models: a contribution of the COST research action TU0801. Int J 3D Inf Model 4:68-76

Bouloukakis M, Partarakis N, Drossis I, Kalaitzakis M, Stephanidis C (2019) Virtual reality for smart city visualization and monitoring. Mediterranean cities and island communities. Springer, Cham, pp 1-18

Chundeli FA (2017) Using 3D GIS as a decision support tool in urban planning. In: Proceedings of the 10th international conference on theory and practice of electronic governance. ACM, New York, pp 401-404

Cook IR, Swyngedouw E (2014) Cities, nature and sustainability. In: Paddison R, McCann E (eds) Cities \& social change. Sage, Thousand Oaks, pp 168-185

Couch C, Petschel-Held G, Leontidou L (eds) (2008) Urban sprawl in Europe: landscape, land-use change and policy. Wiley, London

Czyńska K, Rubinowicz P (2019) Classification of cityscape areas according to landmarks visibility analysis. Environ Impact Assess Rev 76:47-60

Danese M, Nolè G, Murgante B (2009) Visual impact assessment in urban planning. In: Murgante B, Borruso G, Lapuci A (eds) Geocomputation and urban planning. Springer, Berlin, pp 133-146

Fistola R (2009) GIS Teoria ed applicazioni per la pianificazione la gestione e la protezione della città. Gangemi editore, Roma

Fistola R, Rastelli A (2018) Nuove tecnologie e futuro della città: il governo "aumentato" delle trasformazioni urbane. Urbanistica Informazioni. Special Issue 263. http://hdl.handle.net/20.500.12070/38989

Frantzeskaki N, Broto VC, Coenen L, Loorbach D (2017) Urban sustainability transitions, vol 5. Taylor \& Francis, Basingstoke

Gargiulo C (1995) La città come sistema dinamicamente complesso. Studi Urbanistici. Giuffrè, Roma, pp 66-78. ISBN 88-14-05263-8

Gargiulo C (2009) Sistema Urbano e Complessità. In: Papa R (ed) II governo delle trasformazioni urbane e territoriali Metodi, tecniche e strumenti. Franco Angeli, Milano, pp 23-46

Gargiulo C, Lombardi C (2016) Urban retrofit and resilience: the challenge of energy efficiency and vulnerability. Tema J Land Use Mob Environ 9(2):137-162. https://doi.org/10.6092/1970-9870/3922

Gargiulo C, Russo L (2017) Cities and energy consumption: a critical review. Tema J Land Use Mob Environ 10(3):259-278. https://doi. org/10.6092/1970-9870/3922

Gargiulo C, Sforza A, Sterle C, Zucaro F (2018) An optimization model fitting the neighborhood sustainability assessment tools. Sustainability 10(10):3365

Gibbs HK, Salmon JM (2015) Mapping the world's degraded lands. Appl Geogr 57:12-21. https://doi.org/10.1016/j.apgeog.2014.11.024

Government of Malta, Ministry of Health, the Elderly and Community Care (2011) Annual report 2011, Health Care Services

Han H, Yang C, Song J (2015) Scenario simulation and the prediction of land use and land cover change in Beijing, China. Sustainability 7(4):4260-4279
He C, Han Q, de Vries B, Wang X, Guochao Z (2017) Evaluation of sustainable land management in urban area: a case study of Shanghai, China. Ecol Ind 80:106-113

Julin A, Jaalama K, Virtanen JP, Pouke M, Ylipulli J, Vaaja M et al (2018) Characterizing 3D city modeling projects: towards a harmonized interoperable system. ISPRS Int J Geo-Inf 7(2):55

Koens K, Postma A, Papp B (2018) Is overtourism overused? Understanding the impact of tourism in a city context. Sustainability 2018(10):4384

La Rocca RA (2014) The role of tourism in planning the smart city. TeMA J Land Use Mob Environ 7(3):268-282. https://doi.org/10.6092/1970-9870/2814

Lambin EF, Baulies X, Bockstael N, Fischer G, Krug T, Leemans R, Moran EF, Rindfuss RR, Skole D, Turner II BL et al (1999) Land-use and land-cover change: implementation strategy; IGBP Report No. 48/IHDP Report No. 10. IGBP Secretariat, Stockholm, pp 125-126

Luo X, Lu X, Jin G, Wan Q, Zhou M (2019) Optimization of urban land-use structure in china's rapidly developing regions with eco-environmental constraints. Phys Chem Earth A/B/C 110:8-13

Maciocco G, Serreli S (2009) Enhancing the city: new perspectives for tourism and leisure. Enhancing the city. Springer, Dordrecht, pp 1-15

Malta Planning and Environment Authority (2006) Local plan. https://www. pa.org.mt/en/local-plan-details/gozo-comino-local-plan

Malta Ministry for Tourism (2015) National tourism policy. https://tourism.gov. $\mathrm{mt} /$. Accessed 02 Feb 2019

Malta Tourism Authority (2015) Market profile surveys. http://www.mta.com. mt/index.pl/index.plmalta_tourism_digestmarket_profile_surveys. Accessed 25 Feb 2019

Malta Tourism Authority (2018) Market profile surveys. http://www.mta.com. mt/index.pl. Accessed 9 Mar 2019

Martellozzo F, Amato F, Murgante B, Clarke KC (2018) Modelling the impact of urban growth on agriculture and natural land in Italy to 2030. Appl Geogr 91:156-167

Marzec RP (2018) Securing the future in the anthropocene: a critical analysis of the millennium ecosystem assessment scenarios. Elem Sci Anth 6(1):42. https://doi.org/10.1525/elementa.294

MEA-Millennium Ecosystem Assessment (2005) Ecosystems and human wellbeing: scenarios. Findings of the scenarios working group. Island Press, Washington D.C

NSO_National statistics office (2018) Tourism and education statistics. https:// nso.gov.mt/en/View_by_Unit/Tourism_Statistics. Accessed 07 Jan 2019

O'Reilly T (2009) What is web 2.0. O'Reilly Media, Inc, Newton

Papa R (2009) II governo delle trasformazioni urbane e territoriali. Franco Angeli, Milano

Papa R, Angiello G, Carpentieri G (2017) II Governo del Sistema Integrato CittàTrasporti-Energia, vol 3. FedOA-Federico II University Press, Napoli

Plumptre AJ, Baisero D, Jędrzejewski W, Kühl H, Maisels F, Ray JC, Sanderson EW, Strindberg S, Voigt M, Wich S (2019) Are we capturing faunal intactness? A comparison of intact forest landscapes and the "last of the wild in each ecoregion". Front For Glob Change 2:1-10. https://doi.org/10.3389/ ffgc. 2019.00024

Prandi F, Soave M, Dev F, Andreolli M, de Amicis R (2014) Services oriented smart city platform based on 3D city model visualization. In: ISPRS annals of the photogrammetry, remote sensing and spatial information sciences, proceedings of ISPRS technical commission IV symposium, vol II. Copernicus Publications, Gottingen, pp 59-64

Roggema R (2016) The future of sustainable urbanism: a redefinition. City Territory Archit. https://doi.org/10.1186/s40410-016-0052-y

Shiode N, Yin L (2008) Spatial-temporal visualization of built environments. In: Hornsby K, Yuan M (eds) Understanding Dynamics of geographic domains. CRC Press, London, pp 133-150

Steinicke F, Hinrichs K, Ropinski T (2006) A hybrid decision support system for 3D city planning. Int Arch Photogramm Remote Sens Spat Inf Sci XXXVI:103-108

Templin T, Brzezinski G, Rawa M (2019) Visualization of spatio-temporal building changes using 3D web GIS. In: IOP conference series: earth and environmental science, vol 221, no. 1. IOP Publishing, Bristol, $p$ 012084

Troisi J (2009) Ageing in the Maltese Islands'. In: Palmore EB, Whittington F, Kunkel SR (eds) International handbook on aging. Miami University, Oxford

UNDP (2010) The real wealth of nations: pathways to human development (Human Development Report) 
UN-United Nations, Department of Economic and Social Affairs, Population Division (2013) World mortality report 2016 (United Nations publication). http://www.un.org/en/development/desa/population/publications. Accessed 05 Jan 2019

Van der Borg J (2004) Tourism management and carrying capacity in heritage cities and sites. In: Coccossis H, Mexa A (eds) The challenge of tourism carrying capacity assessment: theory and practice. CABI, Wallingford, pp $163-179$

Vojnovic I (2014) Urban sustainability: research, politics, policy and practice. Cities 41:S30-\$44

Yin L, Hastings J (2007) Capitalizing on Views: assessing Visibility Using 3D Visualization and GIS Technologies for Hotel Development in the City of Niagara Falls, USA. J Urban Technol 14(3):59-82

Yin L, Shiode N (2014) 3D spatial-temporal GIS modeling of urban environments to support design and planning processes. J Urban Int Res Placemaking Urban Sustain 7(2):152-169
Young AF (2016) Adaptation actions for integrated climate risk management into urban planning: a new framework from urban typologies to build resilience capacity in Santos (SP). City Territory Archit. https://doi. org/10.1186/s40410-016-0042-0

Zhang X, Wu Y, Shen L (2011) An evaluation framework for the sustainability of urban land use: a study of capital cities and municipalities in China. Habitat Int 35(1):141-149

Zucaro F, Morosini R (2018) Sustainable land use and climate adaptation: a review of European local plans. TeMA J Land Use, Mobility Environ 11(1):7-26. https://doi.org/10.6092/1970-9870/5343.

\section{Publisher's Note}

Springer Nature remains neutral with regard to jurisdictional claims in published maps and institutional affiliations.

\section{Submit your manuscript to a SpringerOpen ${ }^{\circ}$ journal and benefit from:}

- Convenient online submission

- Rigorous peer review

- Open access: articles freely available online

- High visibility within the field

- Retaining the copyright to your article

Submit your next manuscript at $\gg$ springeropen.com 